\title{
Evaluation of anti-inflammatory, antinociceptive and antipyretic effects of methanol extract of Cleome chelidonii
}

\author{
S. PARIMALAKRISHNAN * , AKALANKA DEY, A. ANTON SMITH and R. \\ MANAVALAN
}

Department of Pharmacy, Annamalai University, Annamalai Nagar - 608 002, India.

*Corresponding author, E-mail: kalki.vijay@yahoo.co.in

\begin{abstract}
The methanol extract of Cleome chelidonii whole plant was investigated for its anti-inflammatory, antinociceptive and antipyretic activities at the doses of 50,100 and $200 \mathrm{mg} / \mathrm{kg}$ of body weight. The experimental paradigms used were carrageenan-induced pedal edema for anti-inflammatory activity; acetic acid-induced writhing and hot plate methods to assess antinociceptive activity and yeast-induced hyperpyrexia to evaluate the antipyretic activity. In acute phase inflammation, at dose of $200 \mathrm{mg} / \mathrm{kg}$ of body weight after 3 hours treatment with methanol extract of $C$. chelidonii in carrageenan showed a maximum inhibition of $54.6 \%$ $(\mathrm{P}<0.05)$ when compared with standard drug aspirin $(10 \mathrm{mg} / \mathrm{kg})$, which showed decreased formation of granuloma tissue by $60.6 \%(\mathrm{P}<0.01)$. The methanol extract possesses significant $(\mathrm{P}<0.05)$ antinociceptive activity in both paradigms. In rats a significant $(\mathrm{P}<0.01)$ reduction in hyperpyrexia was also produced by the extract. This study exhibits that the methanol extract of entire plant of $C$. chelidonii possesses antiinflammatory, antinociceptive and antipyretic activities.
\end{abstract}

(C) 2007 International Formulae Group. All rights reserved.

Keywords: Cleome chelidonii, anti-inflammatory, antinociceptive, antipyretic.

\section{INTRODUCTION}

Inflammation is a pathophysiological response of living tissue to injuries that leads to the local increase of plasmatic fluid and blood cells. Although it is a defense mechanism, the complex events and mediators involved in the inflammatory reaction can induce, maintain or aggravate many diseases (Dagmar et al., 2004). However, research work has been going on in inflammatory diseases and the side effects of the currently available anti-inflammatory drugs pose a major problem during their clinical use (Seibert et al., 1994). Therefore, development of newer and more powerful antiinflammatory drugs with lesser side effects is necessary.

The management and treatment of pain is probably one of the most widespread and yet the most difficult aspect to find out a remedy. Analgesic therapy is currently dominated by two major classes of analgesic drugs, namely opioids and non steroidal antiinflammatory drugs (NSAIDs). Both classes of analgesic drugs produce serious adverse effects, such as GI disturbances, renal damages (with NSAIDs drugs), respiratory depression and possibly dependence (with opioids). It is understandable that proposition of analgesic agents with fewer adverse effects is desirable. One of the ways to achieve this aim is the use of medicinal plants, which are a rich source of new potentially effective compounds (Mahmood et al., 2004).

Cleome chelidonii (L.) Linn var. (CC) (synonym/other Latin name is Polanisia chelidonii DC) is a traditional plant belonging to the family Capparaceae. It is grown as perennials through out dry seasons. It has a pink or white colour flowers. The leaves of $\mathrm{CC}$ are claimed to have medicinal properties. $\mathrm{CC}$ is generally known for the treatment of colic, dysentery, headache, otitis, and rheumatism (Kirtikar et al., 1987). It has also 
been found to possess multiple therapeutic properties like vermifuge and skin diseases (Chopra et al., 1992). CC contains glucocapparin and glucocleomin (Songsak et al., 2002). However, no scientific data are available to prove the effects of the folklore claim. Hence this study was undertaken to establish scientific data for the a) antiinflammatory activity using carrageenan induced paw edema in rats b) analgesic potential of the methanol extract of CC on acetic acid-induced writhing test and hot plate reaction time in albino mice and c) antipyretic activity of the methanol extract of CC using yeast-induced pyrexia on rats.

\section{MATERIALS AND METHODS \\ Preparation of the extract}

The samples (entire plant) of Cleome chelidonii were collected from Sengottai of Tamilnadu, India. The plant material was taxonomically identified and authenticated by the Department of Botany, Annamalai University, Annamalainagar, India. The samples were cleaned, dried under shade, powdered by a mechanical grinder and stored in an airtight container. Methanol was used as solvent in the extraction process. The methanol extract was prepared by using dried coarse material of the whole plant and methanol (yield 2.78\%), in a soxhlet apparatus. The methanol extract of Cleome chelidonii was suspended in $1 \%$ gum acacia and was administered to the animals at the doses of 50,100 and $200 \mathrm{mg} / \mathrm{kg}$ of body weight for each group except the control group in all the experiments.

\section{Animals}

Swiss albino mice (25-30 g) and Wistar albino rats $(150-200 \mathrm{~g})$ of both sexes were procured from the central animal house of the institute. They were kept in standard polypropylene cages maintained under standard room temperature $\left(20 \pm 4{ }^{\circ} \mathrm{C}\right.$; relative humidity $60-70 \%$ ) in a 12 hours darklight cycle. The animals were fed with standard pellet diet and water ad libitum as usual. The experiments were conducted after getting the prior approval from the IAEC permission.

\section{Chemicals and Drugs used}

The chemicals and drugs used were carrageenan (Sigma - Aldrich), acetic acid
(Sigma - Aldrich). Aspirin (Vikash Pharma), paracetamol (Calpol) and morphine (Modi Mundi Pharma) were used as standard drugs.

\section{Anti-inflammatory Models}

The anti-inflammatory activity was done by the method of Mahat et al. (2007) and Gupta et al. (2005). The animals were divided into 5 groups $(\mathrm{n}=6$ per group). Acute inflammation was produced by subplantar injection of $0.1 \mathrm{ml}$ of $1 \%$ suspension of carrageenan with $2 \%$ mucilage in normal saline, in the right hind paw of the rats. After the administration of the carrageenan, the paw volume was measured plethysmometrically at 0 and 3rd hour. Difference between the two readings was taken as the volume of edema and the percentage of anti-inflammatory activity was calculated. The ratio of the antiinflammatory effect of methanol extract of $C$. chelidonii was calculated by the following equation:

$$
\operatorname{AIA}(\%)=(1-\mathrm{P} / \mathrm{SC}) \times 100
$$

where,

AIA = Anti-inflammatory activity;

$\mathrm{P}$ represents the percentage difference of paw volume after administration of drugs;

$\mathrm{SC}$ represents the percentage difference of paw volume in the control groups.

Aspirin $100 \mathrm{mg} / \mathrm{kg}$, p.o suspended in $2 \%$ mucilage was used as the standard drug.

\section{Acetic acid-induced writhing test}

The antinocicepitve effect was determined by the method of Gupta et al. (2005) and Huo et al. (2007). Acetic acid in distilled water $(0.6 \%)$ at the dose of $10 \mathrm{ml} / \mathrm{kg}$ of body weight was injected intraperitoneally (i.p.). The number of writhes after 30 minutes was counted. Aspirin in dose of $100 \mathrm{mg} / \mathrm{kg}$, suspended in $2 \%$ mucilage was used as the standard drug. Then the percentage inhibition of writhing was calculated.

\section{Hot plate reaction time in mice}

The antinocicepitve activity was estimated by the method of Huo et al. (2007) and Prashant et al. (2005). Mice were prescreened by placing them on a hot plate maintained at $55 \pm 1{ }^{\circ} \mathrm{C}$ and the reaction time (in seconds) for hind paw licking or jumping was recorded. Mice which reacted within 15 seconds and which did not show large variation when tested on four separate 
occasions (each 15 minutes apart) were used for the study. Morphine $(5 \mathrm{mg} / \mathrm{kg}$, i.p.) was used as a standard drug. The time for hind paw licking or jumping on the heated plate of analgesiometer was taken as the reaction time.

\section{Induction of Yeast-induced pyrexia}

The antipyretic property was measured by the method reported by Nisar et al. (2007). $20 \mathrm{ml} / \mathrm{kg}$ of $20 \%$ aqueous suspension of sterilized brewer's yeast powder was administered to the rats subcutaneously. After 24 hours, animals showing an increase of rectal temperature $>0.5{ }^{\circ} \mathrm{C}$ were selected. Animals were divided into five groups of six rats in each group and were trained to remain quiet in a restraint cage. Normal saline was administered to control group; while experimental group received doses of 50, 100 and $200 \mathrm{mg} / \mathrm{kg}$ of body weight of the methanol extract. The fifth group of animals received the standard drug paracetamol (150 $\mathrm{mg} / \mathrm{kg}$ of body weight) orally. Rectal temperature was measured at 30 minutes before administration and at 30 minutes, 1, 2 and 4 hours after administration by using thermal-probe.

\section{Statistical analysis}

Values in the test and tables are represented as Mean $\pm \mathrm{SEM}$. The results were analyzed for statistical significance using oneway ANOVA followed by Dunnet's test. A P value $<0.05$ was considered significant.

\section{RESULTS}

\section{Anti-inflammatory studies}

The methanol extract of $C$. chelidonii (50, 100 and $200 \mathrm{mg} / \mathrm{kg})$ against various experimental animal models exhibited significant $(\mathrm{P}<0.05)$ anti-inflammatory activity. The effects of methanol extract of $C$. chelidonii and aspirin on the inflammation (induced by carrageenan which forms granuloma) are summarized in figure 1 . The methanol extract of $C$. chelidonii showed maximum inhibition of $54.6 \%$ at the dose of $200 \mathrm{mg} / \mathrm{kg}$ after 3 hours of treatment in carrageenan-induced paw edema, whereas the standard drug (aspirin $10 \mathrm{mg} / \mathrm{kg}$ ) showed $70.4 \%$ of inhibition $(\mathrm{P}<0.05)$.

\section{Acetic acid-induced writhing in mice}

The results presented in table 1 showed $15.5 \%, 25.8 \%$ and $45.8 \%$ significant $(\mathrm{P}<$ $0.01)$ inhibition of control writhes by methanol extract of $C$. chelidonii at the doses of 50,100 and $200 \mathrm{mg} / \mathrm{kg}$ of body weight respectively and $64.0 \%$ significant $(\mathrm{P}<0.01)$ inhibition by aspirin $(100 \mathrm{mg} / \mathrm{kg})$.

\section{Hot plate reaction time in mice}

The result presented in table 2 , showed that the methanol extract of $C$. chelidonii has produced $(\mathrm{P}<0.01)$ antinociceptive activity at all the tested doses when compared to that of control group.

\section{Yeast-induced Hyperpyrexia}

The results of the antipyretic activity of the extracts are presented in table 3. The subcutaneous injection of yeast suspension marked elevated rectal temperature after 24 hours of administration. All the doses of the extracts showed a significant antipyretic effect like the standard drug paracetamol. The result obtained from both the standard drug and methanol extract of $C$. chelidonii-treated rats were compared with the control group and a significant $(\mathrm{P}<0.01)$ reduction in rectal temperature of yeast-induced rats was observed.

Table 1: Effects of methanol extract of $C$. chelidonii and aspirin on writhing induced by acetic acid in mice.

\begin{tabular}{lccc}
\hline Treatment & Dose (mg/kg) & $\begin{array}{c}\text { Number of writhes } \\
\text { (per 30 min) }^{\mathbf{a}}\end{array}$ & Inhibition (\%) \\
\hline Control & -- & $29.33 \pm 2.24$ & -- \\
CCME & 50 & $25.00 \pm 1.97$ & 15.50 \\
CCME & 100 & $23.43 \pm 1.04^{\mathrm{b}}$ & 25.80 \\
CCME & 200 & $17.55 \pm 1.59^{\mathrm{b}}$ & 45.80 \\
Aspirin & 100 & $15.00 \pm 0.90^{\mathrm{b}}$ & 64.00 \\
\hline a The results given are mean \pm S.E.M.; $\mathrm{n}=6$ animals in each group & \\
b P $<0.01$, Experimental groups were compared with control & \\
CCME: Methanol extract of C. chelidonii &
\end{tabular}




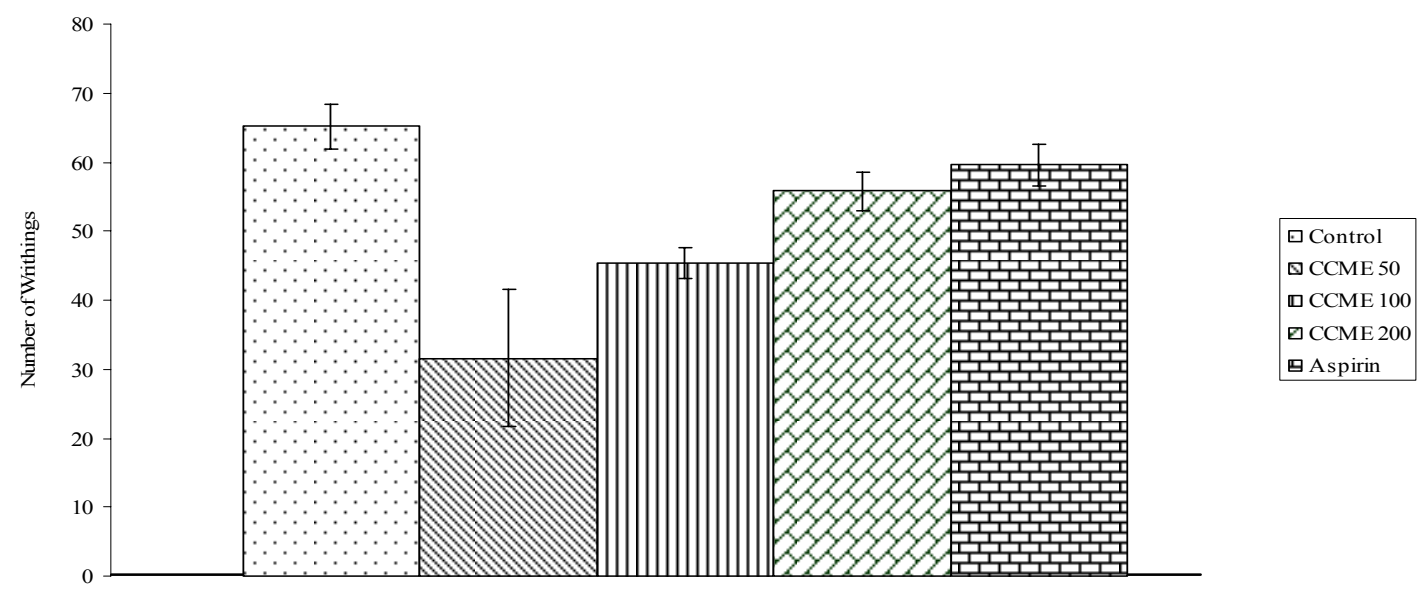

Figure 1: Effect of CCME and aspirin on carrageenan-induced rat paw edema. Difference of means of edema volume $(\mathrm{ml})$ between control and treatment values at different doses \pm S.E.M. Variation compared to the control animals. CCME: Methanol extract of C. chelidonii

Table 2: Effects of methanol extract of $C$. chelidonii and morphine on hot plate reaction time in mice.

\begin{tabular}{|c|c|c|c|}
\hline \multirow{2}{*}{ Treatment } & \multirow{2}{*}{$\begin{array}{c}\text { Dose } \\
\text { (mg/kg) }\end{array}$} & \multicolumn{2}{|c|}{ Mean latent time $^{a}$} \\
\hline & & Initial & After $30 \mathrm{~min}$ \\
\hline Control & -- & $6.64 \pm 0.42$ & $6.14 \pm 0.36$ \\
\hline CCME & 50 & $7.53 \pm 0.56^{b}$ & $11.34 \pm 1.93$ \\
\hline CCME & 100 & $7.87 \pm 0.79^{b}$ & $12.25 \pm 1.82$ \\
\hline CCME & 200 & $7.20 \pm 0.63$ & $13.74 \pm 1.06$ \\
\hline Morphine & 5 & $7.94 \pm 0.77^{b}$ & $17.17 \pm 1.03$ \\
\hline
\end{tabular}

Table 3: The effect of methanol extract of $C$. chelidonii and paracetamol on yeast induced pyrexia in rats.

\begin{tabular}{|c|c|c|c|c|c|c|}
\hline \multirow{3}{*}{ Treatment } & \multicolumn{6}{|c|}{ Rectal temperature $\left({ }^{\circ} \mathrm{C}\right)^{a}$} \\
\hline & \multicolumn{2}{|c|}{ After yeast injection at } & \multicolumn{4}{|c|}{ After drug administration at } \\
\hline & ohr & 24hr & 1hr & $2 \mathrm{hr}$ & 3hr & 4hr \\
\hline Control & $37.6 \pm 0.02$ & $39.9 \pm 0.03$ & $39.8 \pm 0.02$ & $38.2 \pm 0.05$ & $38.9 \pm 0.05$ & $39.9 \pm 0.04$ \\
\hline CCME $50 \mathrm{mg} / \mathrm{kg}$ & $37.7 \pm 0.07$ & $37.8 \pm 0.03^{\mathrm{b}}$ & $37.5 \pm 0.02$ & $38.7 \pm 0.02^{\mathrm{b}}$ & $39.4 \pm 0.04^{\mathrm{b}}$ & $38.1 \pm 0.06^{\mathrm{b}}$ \\
\hline CCME $100 \mathrm{mg} / \mathrm{kg}$ & $38.6 \pm 0.02$ & $37.7 \pm 0.04$ & $37.8 \pm 0.05^{\mathrm{b}}$ & $38.3 \pm 0.05$ & $39.1 \pm 0.03^{\mathrm{b}}$ & $37.9 \pm 0.06^{\mathrm{b}}$ \\
\hline CCME $200 \mathrm{mg} / \mathrm{kg}$ & $38.7 \pm 0.04$ & $39.9 \pm 0.06$ & $37.7 \pm 0.02^{\mathrm{b}}$ & $39.9 \pm 0.03^{\mathrm{b}}$ & $38.7 \pm 0.05$ & $37.9 \pm 0.04^{\mathrm{b}}$ \\
\hline Paracet. $150 \mathrm{mg} / \mathrm{kg}$ & $37.8 \pm 0.02$ & $39.9 \pm 0.03^{b}$ & $38.9 \pm 0.02$ & $38.5 \pm 0.02^{\mathrm{b}}$ & $39.3 \pm 0.04^{\mathrm{b}}$ & $39.7 \pm 0.03$ \\
\hline
\end{tabular}

\section{DISCUSSION}

Carrageenan-induced rat hind paw edema has been used as a standard inflammation model in order to investigate the acute inflammatory effect of the drug. There are two phases of carrageenan-induced inflammatory reaction: early or first phase and later or second phase. The early phase results from histamine; serotonin and bradykinin liberation and the second phase is associated with the release of prostaglandin and slow reacting substances (Lee et al., 2001). 
In one of the previous study Cleome species C. viscosa methanol extract at 100 , $200 \& 400 \mathrm{mg} / \mathrm{kg}$ of body weight has shown a promising analgesic activity in mice using the acetic acid writhing, tail flick, tail clip and tail immersion methods (Parimaladevi et al., 2003). When compared to this the whole plant of C. chelidonii methanol extract has produced less anti-inflammatory effect.

In another work, the methanol extract of the leaves of C. gynandra exhibited significant anti-inflammatory activity in adjuvant-induced arthritic rats. A significant decrease in paw edema with a remarkable increase in body weight was observed following oral administration of the leaf extract $(150 \mathrm{mg} / \mathrm{kg}$ of body weight). These results demonstrated that the plant extract has no harmful effect and exerts in vivo antiinflammatory properties against adjuvantinduced arthritis (Ogonowski et al., 1997). When compared to this the whole plant of $C$. chelidonii methanol extract has produced less anti-inflammatory effect.

In some other study, antipyretic activity of a methanol extract of $C$. viscosa was investigated for its potential on yeast-induced pyrexia in albino rats, at doses of 200, 300, and $400 \mathrm{mg} / \mathrm{kg}$ body weight p.o. and showed significant reduction in normal body temperature (Bouriche et al., 2005). When compared to this the whole plant of $C$. chelidonii methanol extract has less significant reduction in antipyretic effect.

The effects of C. arabica leaf extract, rutin and quercetin on soybean lipoxygenase (Lox) activity and on calcium ionophore (A23187) stimulated generation of the leukotriene B4 and prostaglandin E2 by human neutrophils were examined. Results indicate that rutin; quercetin and an extract of C. arabica containing these compounds inhibit Lox activity, consequently decreasing LTB4 production. These compounds and extracts containing them may be beneficial for the treatment of inflammatory conditions, particularly those characterized by excessive leukotriene generation (Narendhirakannan et al., 2005).

In this present study, there is an increase in the hind paw volume following carrageenan administration in the control group $(0.50 \pm 0.03 \mathrm{ml})$ and aspirin treated group $(0.21 \pm 0.01 \mathrm{ml})$. A significant anti- inflammatory activity was observed for methanol extract of C. chelidonii in carrageenan model. In carrageenan-induced paw edema the methanol extract of $C$. chelidonii showed maximum inhibition of $54.6 \%$ at the dose of $200 \mathrm{mg} / \mathrm{kg}$ after 3 hours of drug treatment. The methanol extract of $C$. chelidonii produced dose-dependent and significant inhibition of carrageenan-induced paw edema. The inhibition produced was less significant when compared to that of the standard drug.

The abdominal constriction may be related to sensitization of nociceptive receptors to prostaglandins induced by acetic acid, which is a sensitive procedure to establish peripherally acting analgesics. The number of writhing movements during a 30 minutes observation in the control group was $29.33 \pm 2.24$, which corresponds with findings of other workers (Parimaladevi et al, 2003).

In the hot plate method, the test drug in different doses increased the pain threshold significantly during the period of observation and this indicates the involvement of higher center.

Fever may be a result of infection or one of the sequelae of tissue damage, inflammation, graft rejection or other diseases. Antipyretic drugs reduce elevated body temperature. Regulation of body temperature requires a delicate balance between production and loss of heat, and the hypothalamus regulates the set point at which body temperature is maintained. The result obtained from both the standard drug and methanol extract of $C$. chelidonii treated rats were compared with the control group and found to possess significant reduction in the yeast induced rats. In fever this set point is elevated and a drug like paracetamol helps in keeping the body temperature normal when it is elevated by factors such as exercise or increases in ambient temperature (Goodman and Gilman, 1996).

\section{Conclusion}

Based on results of the present study it can be concluded that the methanol extract of C. chelidonii has promising activity against acute phase of inflammation at a dose range of $50-200 \mathrm{mg} / \mathrm{kg}$ body weight and among the three doses the dose of $200 \mathrm{mg} / \mathrm{kg}$ is found to be more potent and efficacious against anti- 
inflammatory effect. However, the analgesic activity of methanol extract of $C$. chelidonii was found to have more significant effect on the acetic acid-induced model than the hot plate method and thus it appears that the extract inhibits predominantly the peripheral pain mechanism. The antipyretic activity also showed a less significant influence when compared with the anti-inflammatory and antinociceptive activity. More detailed phytochemical studies are, however, necessary to identify the active principle(s) and exact mechanism of action.

\section{REFERENCES}

Bouriche H, Miles EA, Selloum L, Calder PC. 2005. Effect of C. Arabica leaf extract, rutin and quercetin on soybean lipoxygenase activity and on generation of inflammatory eicosanoids by human neutrophilis. Prostaglandins Leukot. Essen. Fatty Acids., 72: 195 - 201.

Chopra RN, Nayar SL, Chopra IC. 1992. Glossary of Indian Medicinal Plants. Publications \& Information Directorate, Council of Industry and Research: New Delhi.

Dagmar J, Kateřina K, Ladislav K. 2004. Screening for antimicrobial activity of some medicinal plants species of traditional Chinese medicine. Czech $J$. Food \& Sci., 3: 107 - 110.

Goodman, Gilman. 1996. The Pharmacological Basis of Therapeutics (19th edn). McGraw - Hill: New York.

Gupta M, Mazumder UK, Kumar RS, Gomathi P, Rajeshwar Y, Kakoti BB, Selven VT. 2005. Anti-inflammatory, analgesic and antipyretic effects of methanol extract from B. racemosa stem bark in animal models. $J$. Ethnopharmacol., 3: 267 - 273.

Huo Y, Guo C, Zhang Q.-Y, Chen W.-S, Zheng H.-C, Rahman K, Qin L.-P. 2007. Antinociceptive activity and chemical composition of constituents from Caragana microphylla seeds. Phytomed., 2-3: 143-146.

Kirtikar KR, Basu BD. 1987. Indian Medicinal Plants (2nd edn). International Book Distributors: Dehradun.

Lee JH, Ko WS, Kim YH, Kang HS, Kim HD, Choi BT. 2001. Anti-inflammatory effect of the aqueous extract from $L$. japonica flower is related to inhibition of $\mathrm{NF}$ - kappaB activation through reducing I - kappaBalpha degradation in rat liver. Int. J. Mol. Med., 7: $79-83$.

Mahat MA, Patil BM. 2007. Evaluation of anti-inflammatory activity of methanol extract of Phyllanthus amarus in experimental animal models. IJPS., 1: 33-36.

Mahmood RH, Ali M, Mohsen E. 2004. Antinociceptive effects and toxicity of $F$. parviflora Lam in mice and rats. DARU., 4: $136-140$.

Narendhirakannan RT, Kandaswamy M, Subramanian S. 2005. Anti-inflammtory activity of $C$. gynandra $\mathrm{L}$ on hematological and cellular constituents in adjuvant induced arthritic rats. J. Med. and Food, 8: 93 - 99.

Nisar M, Adzu B, Inamullah K, Bashir A, Ihsan A, Gilani AH. 2007. Antinociceptive and antipyretic activities of the Zizyphus oxyphylla Edgew leaves. Phytother Res., 7: 693-695.

Ogonowski AA, May WS, Moor AB, Barret LT, Bryant CL, Pollock SH. 1997. Antiinflammatory and analgesic activity of an inhibitor of neuropeptide amidation. $J$ Pharmcol Exp Ther., 280: 846 - 853.

Parimaladevi B, Boominathan R, Mandal SC. 2003. Evaluation of antipyretic potential of C. viscosa L (Capparidaceae) extracts in rats. J. Ethanopharmacol., 87: 11 - 13.

Parimaladevi B, Boominathan R, Mandal SC. 2003. Studies on analgesic activity of $C$. viscosa in mice. Fitot., 74: $262-6$.

Prashant RV, Amit AJ, Vivekanand AC, Alpana JA. 2005. Antinociceptive activity of alcoholic extract of Hemidesmus indicus R.Br. in mice. $J$. Ethnopharmacol., 2: 298-301.

Seibert K, Zhang Y, Leahy K, Hauser S, Masferrer J, Perkins W, Lee L, Isakson P. 1994. Pharmacological and biochemical demonstration of the role of cyclooxygenase 2 in inflammations and pain. Proc. Natl. Acad. Sci. U.S.A., 91: $12013-12017$.

Songsak T, Lockwood GB. 2002. Glucosinolates of seven medicinal plants from Thailand. Fitot., 3: 209 - 216. 